\title{
RESEARCHING THE FINANCIAL CYCLE PATTERNS OF THE ECONOMIES OF THE WORLD'S COUNTRIES AND UKRAINE
}

\author{
๑2020 LAKTIONOVA 0. A., BENZAR 0. V.
}

UDC 339.97

JEL: C10; E32; F15; F36

Laktionova O. A., Benzar O. V. Researching the Financial Cycle Patterns of the Economies of the World's Countries and Ukraine

The cyclicality of the world economy necessitates an analysis of the interrelationship between different economic phenomena, as they have a direct impact on the emergence of cyclical shifts in the process of movement of both local and global financial cycles. The article is aimed at analyzing the dynamics of the relevant financial indicators for the countries with advanced economies, developing countries and Ukraine, as well as checking these indicators for cyclicality during the period under review. This analysis is based on a methodical approach to identifying the cyclical nature of the movement of financial cycles, built up with account of the impact of the relevant financial indicators on the patterns of occurrence of fluctuations during the period of 2008-2019. The main economic indicators, characterizing the features of the fluctuations in financial cycles, which are taken as a basis in carrying out the research, are: the level of growth in real GDP; total volume of loans to the non-financial sector of the economy; the ratio indicator of the total volume of loans to the non-financial sector of the economy to nominal GDP; real estate prices index. In analyzing the cyclicality of both local and global financial cycles, the Durbin-Watson criterion was the main statistical criterion for identifying the relationship between existing cycles. The research results in the identified key causes of the corresponding phase of cyclicality of the local financial cycle, depending on the current status of the global financial cycle. The hypothesis of a relationship between the cyclical movement of local and global financial cycles is substantiated. A direct dependence of the movement of the local financial cycle on fluctuations in the global financial cycle is identified.

Keywords: financial cycle, financial integration, Durbin - Watson criterion, GDP, loans, real estate prices index.

DOl: https://doi.org/10.32983/2222-4459-2020-6-252-259

Fig.: 5. Tabl.: 1. Formulae: 3. Bibl.: 13.

Laktionova Oleksandra A. - D. Sc. (Economics), Associate Professor, Head of the Department of Finance and Banking, Vasyl' Stus Donetsk National University (21 600-richchia Str., Vinnytsia, 21021, Ukraine)

E-mail: laktionova.loa@donnu.edu.ua

ORCID: https://orcid.org/0000-0001-6472-6503

Scopus Author ID: 35758779200

Benzar Olena V. - Graduate Student, Vasyl' Stus Donetsk National University (21 600-richchia Str., Vinnytsia, 21021, Ukraine)

E-mail: benzar.o@donnu.edu.ua

ORCID: https://orcid.org/0000-0003-4462-204X

УДК 339.97

JEL: C10; E32; F15; F36

Лактіонова О. А., Бензар О. В. Дослідження закономірностей прояву фінансових циклів країн світу та України

Циклічність світової економіки зумовлює необхідність аналізу взаємозв'язків між різними економічними явищами, оскільки вони мають прямий вплив на виникнення циклічних зрушень у процесі руху як локального, так і глобального фінансових циклів. Метою статті $є$ аналіз особливостей динаміки відповідних фінансових показників для країн з розвиненою економікою; таких, що розвиваються, та України, а також перевірка цих показників на предмет циклічності впродовж аналізованого періоду. Такий аналіз виконується на основі методичного підходу до виявлення циклічного характеру руху фінансових циклів, побудованого з урахуванням впливу відповідних фінансових індикаторів на закономірності виникнення коливань упродовж періоду 2008-2019рр. Основними економічними показниками, що характеризують особливості коливань фінансових циклів, які взяті за базис при проведенні даного дослідження, виступають: рівень зростання реального ВВП; загальний обсяг кредитів, наданих нефінансовому сектору економіки; показник відношення загального обсягу кредитів, наданих нефінансовому сектору економіки, до номінального ВВП; індекс цін на нерухомість. У процесі аналізу циклічності локального та глобального фінансових циклів основним статистичним критерієм для виявлення взаємозв'язку між наявними циклами служив критерій Дарбіна -Уотсона. В результаті дослідження було виявлено ключові причини виникнення відповідної фази циклічності локального фінансового циклу залежно від поточного стану глобального фінансового циклу. Обгрунтовано гіпотезу про наявність взаємозв'язків між циклічним рухом локального та глобального фінансових циклів. Виявлено безпосередню залежність руху локального фінансового циклу від коливань глобального фінансового циклу.

Ключові слова: фінансовий цикл, фінансова інтеграція, критерій Дарбіна - Уотсона, ВВП, кредити, індекс цін на нерухомість.

Рис.: 5. Табл.: 1. Формул: 3. Бібл.: 13.

Лактіонова Олександра Анатоліївна - доктор економічних наук, доцент, завідувачка кафедри фінансів і банківської справи, Донецький національний університет імені Василя Стуса (вул. 600-річчя, 21, Вінниия, 21021, Україна)

E-mail: Iaktionova.loa@donnu.edu.ua

ORCID: https://orcid.org/0000-0001-6472-6503

Scopus Author ID: 35758779200

Бензар Олена Вячеславівна - магістрантка, Донецький національний університет імені Василя Стуса (вул. 600-річчя, 21, Вінниця, 21021, Україна) E-mail: benzar.o@donnu.edu.ua ORCID: https://orcid.org/0000-0003-4462-204X

УДК 339.97

JEL: C10; E32; F15; F36

Лактионова А. А., Бензар Е. В. Исследование закономерностей проявления циклического характера финансовых циклов стран мира и Украины Цикличность мировой экономики вызывает необходимость анализа взаимосвязей между различными экономическими явлениями, так как они оказывают прямое влияние на возникновение циклических сдвигов в процессе движения как локального, так и глобального финансовых циклов. Целью статьи является анализ особенностей динамики соответствующих финансовых показателей для стран с развитой экономикой, разви- 
вающихся стран и Украины, а также проверка этих показателей на предмет цикличности в течение рассматриваемого периода. Такой анализ выполняется на основе методического подхода к выявлению циклического характера движения финансовых циклов, построенного с учетом влияния соответствующих финансовых индикаторов на закономерности возникновения колебаний в течение периода 2008-2019 гг. Основными экономическими показателями, характеризующими особенности колебаний финансовых циклов, которые взяты за базис при проведении данного исследования, выступают: уровень роста реального ВВП; общий объем кредитов, предоставленных нефинансовому сектору экономики; показатель отношения общего объема кредитов, предоставленных нефинансовому сектору экономики, к номинальному ВВП; индекс цен на недвижимость. В процессе анализа цикличности локального и глобального финансовых циклов основным статистическим критерием для выявления взаимосвязи между имеющимися циклами служил критерий Дарбина-Уотсона. В результате исследования были выявлены ключевые причины возникновения соответствующей фазы цикличности локального финансового цикла в зависимости от текущего состояния глобального финансового цикла. Обоснована гипотеза о наличии взаимосвязей между циклическим движением локального и глобального финансовых циклов. Выявлена непосредственная зависимость движения локального финансового цикла от колебаний глобального финансового цикла.

Ключевые слова: финансовый цикл, финансовая интеграция, критерий Дарбина - Уотсона, ВВП, кредиты, индекс цен на недвижимость.

Рис.: 5. Табл.: 1. Формул: 3. Библ.: 13.

Лактионова Александра Анатольевна - доктор экономических наук, доцент, заведующая кафедрой финансов и банковского дела, Донецкий национальный университет имени Василя Стуса (ул. 600-летия, 21, Винница, 21021, Украина)

E-mail: laktionova.loa@donnu.edu.ua

ORCID: https://orcid.org/0000-0001-6472-6503

Scopus Author ID: 35758779200

Бензар Елена Вячеславовна - магистрантка, Донецкий национальный университет имени Василя Стуса (ул. 600-летия, 21, Винница, 21021, Украина) E-mail: benzar.o@donnu.edu.ua

ORCID: https://orcid.org/0000-0003-4462-204X

$\mathrm{T}$ he issue of reducing negative effects of the global economic crisis is on the agenda in professional sphere of the world community and a matter of concern of governments all over the world. Under conditions of financial integration and globalization, timely analysis of the patterns of financial cycles at both global and local levels is required. It is intended for early detection of signals of possible imbalances and early warning of crisis phenomena in the economy, a long recession, with regard to the cyclical influence of the behavior of financial indicators on these phenomena. Examining the relationship between key financial and economic macroeconomic indicators that reflect cyclical development is crucial for ensuring both global and local financial equilibrium.

Theoretical aspects of the essence of the financial cycle and its role in shaping the cyclical patterns of economic development are formulated by a number of foreign scientists including C. Borio, H. Rey, N. Kennedy, S. Prowse, P. Disyatat, etc. A significant contribution to the methodology of analysis and research of financial cycles is made by M. Drehmann, C. Borio and K. Tsatsaronis [1], who use in their research two approaches to measuring the financial cycle: turning point analysis and bandpass filter developed by L. Christiano and T. Fitzgerald [2]. The aforementioned scientists created a theoretical and methodological basis for studying financial cycles, but there is a need for a more thorough investigation of the characteristics of financial cycles of countries with different levels of economic development. The issue of analyzing the patterns of the financial cycle of Ukraine and investigating the causal relationship of certain changes at the local level with the situation at the global level remains relevant.

The aim of the article is to analyze the patterns of cyclical fluctuations of local financial cycles of countries with different economic development including Ukraine and to study their relationship with the global financial cycle.

The periodicity and nature of fluctuations in domestic and global financial cycles are inherent signs of cyclicality. The dynamic patterns and trends in cycles are determined by the influence of changes in a number of economic and financial indicators that are directly related to the occurrence of cyclical shifts in local and global financial cycles.

$\mathrm{T}$ o study financial cycles, many scientists formed an appropriate system of indicators to assess the nature of cyclicality. In particular, H. Rey [3] in her research associates frequency of financial cycles with movement of asset prices and gross capital flows. G. Gorton and G. Ordonez [4] substantiate the effectiveness of asset prices and loans as financial indicators to investigate financial cycles. On the other hand, P. Giordani with his co-authors [5] identify indicators that characterize the dynamic patterns of financial cycle in the early stages: the credit-to-GDP gap, house prices, and the ratio of unstable over stable sources of funding of the banking sector. At the same time, in [6] O. Jordà and the co-authors highlight the vision of analyzing financial cycles by the comovement of internal financial variables, namely: real credit (measured by total loans), real house prices, and real equity prices. Indicators identified by the scientists are directly related to the main economic phenomena in the functioning of both individual countries and the global economic system.

The study and analysis of the periodicity of financial cycles has received sufficient attention at the global level. However, today it is important to study the relationship between domestic and global financial cycles by the appropriate division of countries into groups according to economic development: developed countries and devel- 
oping ones. The issue of analyzing the nature of the impact of global financial cycle on the financial cycle in Ukraine is also relevant. Thus, the main tasks are as follows:

+ investigating certain financial indicators for their cyclicality during 2008-2019;

+ checking the cyclicality of indicators of financial cycles in groups of countries and Ukraine by calculating the Durbin - Watson statistic;

+ determining the relationship between cyclical fluctuations of local and global financial cycles.

The methodology of this study includes the following steps:

1. Construction of a trend line for the time series of the relevant financial indicator and selection of the best variant of the trend line, focusing on the value of the coefficient of determination.

2. Test the hypothesis for the presence of autocorrelation in the residuals by calculating the Durbin Watson statistic.

3. If there is autocorrelation between the data, the analysis should be continued to identify periodicity. In the absence of autocorrelation - it is necessary to hypothesize the random nature of fluctuations and lack of periodicity.

4. Calculation of the autocorrelation coefficient of deviations of the residuals for each data series.

5. Verification of the pre-calculated coefficient for significance according to the Student's t-test.

6. Reiteration of Steps 4 and 5 for lags $2,3, \ldots, n$ until in Step 5 the autocorrelation coefficient of deviations becomes significant.

7. The last significant autocorrelation coefficient determines the frequency lag.

$\mathrm{T}$ he process of analyzing the cyclical nature of local and global financial cycles aims to study the nature of fluctuations in the relevant financial indicators during 2008-2019 in the two groups of countries and Ukraine. Financial indicators directly related to the analysis of the nature of cyclical shifts in local and global financial cycles are the following: the level of real GDP growth, total loans to the non-financial sector, the ratio of total loans to GDP, and the real estate price index.

The key element in determining the nature and frequency of fluctuations in the financial cycle is the level of real GDP growth. This indicator allows to determine the periods of booms and busts of both local and global financial cycle. First of all, trend lines to describe the behavior of this economic indicator in two groups of countries and Ukraine (Fig. 1) were constructed. The second step was to calculate the Durbin - Watson (DW) statistic to detect the autocorrelation of first-order residuals. This statistic is most often used to check the presence of autocorrelation of residuals and is calculated by the following formula:

$$
D W=\frac{\sum_{t=1}^{n}\left(e_{t+1}-e_{t}\right)^{2}}{\sum_{t=1}^{n} e_{t}^{2}}, D W \in[0 ; 4],
$$

where $e_{t}$ is random deviations from the trend or regression model: $e_{t}=y_{t}-y(x)$.

The algorithm for detecting autocorrelation of residuals based on the Durbin - Watson test implies identifying the appropriate hypothesis: positive or negative autocorrelation in residuals or no autocorrelation of residuals. With the positive autocorrelation $D W<2$, and with the negative $-D W>2$. The actual values of the statistic are compared with the critical (tabular) for a different number of observations $n$ and the number of independent variables $m$ for the selected level of significance $\alpha$. The tabular values have a lower limit $d_{1}$ and an upper limit $-d_{2}$ [8]. According to these values, the numerical interval $[0 ; 4]$ is divided into five segments. Acceptance or rejection of each of the hypothesis is as follows (Fig. 2).

$\mathrm{T}$

he calculation of the Durbin - Watson statistic for the level of real GDP growth in the group of developed countries (Tbl. 1) showed that according to the tabular values at $m=1$ the critical points for the significance level of 0.01 and the number of observations 12 are as follows: $d_{1}=0.697$ and $d_{2}=1.023$, respectively. The obtained critical values are the general limits for the analysis of the following financial indicators. As a result, the Durbin - Watson $(D W)$ statistic is equal to 3.006, i. e. $2.977<D W<3.033\left(4-d_{2}<D W<4-d_{1}\right)$, this suggests the need to further verify the presence of autocorrelation with other lags of delay, as the value obtained is in zone of uncertainty.

Thus, the next stage of the analysis will be the calculation of the autocorrelation coefficient of deviations of the residuals of this indicator according to the following formula:

$$
R_{e_{t} e_{t+1}}=\frac{\sum_{t=1}^{n-1} e_{t} e_{t+1}}{\frac{e_{t}^{2}}{2}+\sum_{t=2}^{n-1} e_{t}^{2}+\frac{e_{n}^{2}}{2}} .
$$

The value of the coefficient ranges from -1 to +1 , in the absence of autocorrelation $R_{e_{t} e_{t+1}}=0$. In the case of a group of countries with developed economies, the autocorrelation coefficient of deviations of the residuals is equal to $(-0.52)$. This result must also be checked for statistical significance of the presence of autocorrelation with a certain lag of delay using the Student's t-test:

$$
t_{p}=\frac{\left|R_{l}\right| \sqrt{n-l-2}}{\sqrt{1-R_{l}^{2}}} .
$$

Using the tables of t-distribution, we found the tabular value of the criterion $\left(t_{a}\right)$ with the number of degrees of freedom $m=n-1-2$ and a given level of statistical significance $\alpha$. According to the analysis with the available number of degrees of freedom $m=9$ and the level of statistical significance of $5 \%, t_{a}=2.262$. Thus, $t_{p}$ with the value of 1.827 was obtained. Therefore, $t_{p}<t_{a}$, which indicates the insignificance of this parameter, so there is a need to repeat the previous steps for subsequent lags. 
Rate, \%

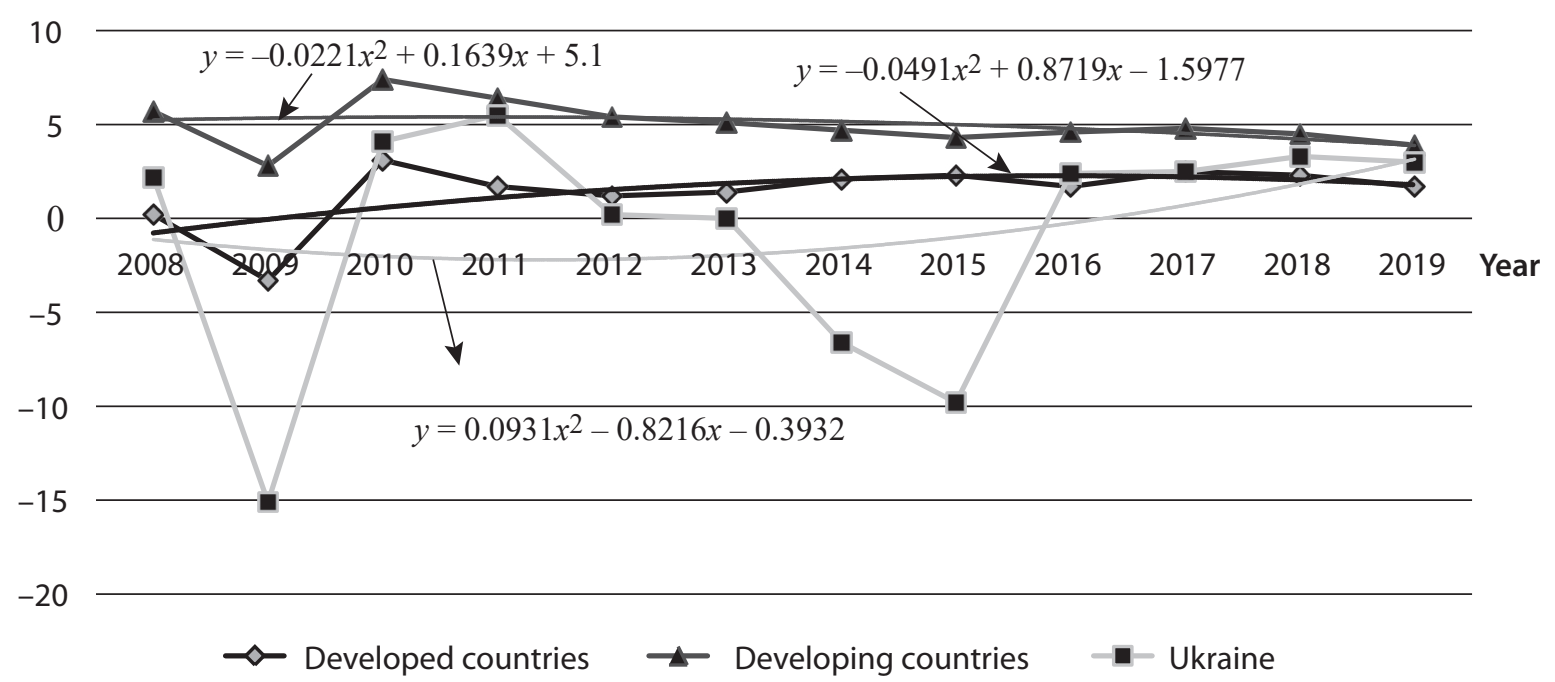

Fig. 1. Real GDP growth rate (annual percentage change compared to the previous year) for developed countries, developing countries and Ukraine (2008-2019)

Source: compiled by [7].

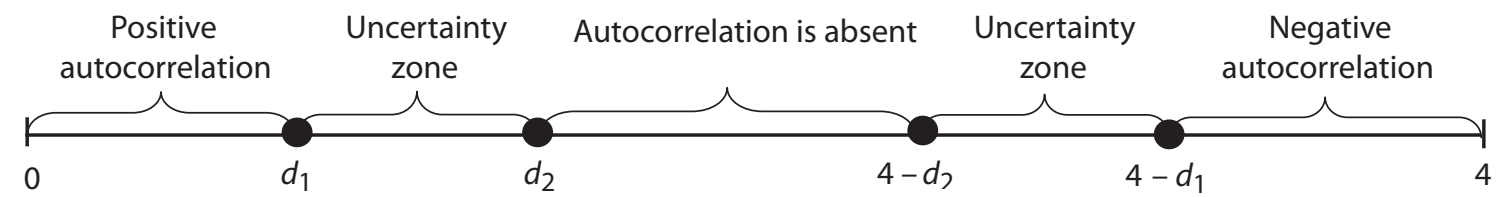

Fig. 2. Algorithm for testing the hypothesis of the presence of autocorrelation of residuals

Source: compiled by [8].

Table 1

Calculation of the Durbin - Watson statistic for the level of real GDP growth in developed countries

\begin{tabular}{|c|c|c|c|c|c|c|}
\hline Year & $y$ & $y(x)$ & $e_{t}$ & $e_{t}^{2}$ & $\left(e_{t}-e_{t-1}\right)^{2}$ & $D W$ \\
\hline 2008 & 0.20 & -0.77 & 0.97 & 0.95 & 0 & \\
\hline 2009 & -3.30 & -0.05 & -3.25 & 1.56 & 17.85 & \\
\hline 2010 & 3.10 & 0.58 & 2.52 & 6.37 & 33.33 & \\
\hline 2011 & 1.70 & 1.10 & 0.60 & 0.35 & 3.72 & \\
\hline 2012 & 1.20 & 1.53 & -0.33 & 0.11 & 0.86 & \\
\hline 2013 & 1.40 & 1.87 & -0.47 & 0.22 & 0.02 & \\
\hline 2014 & 2.10 & 2.10 & 0 & 0 & 0.22 & \\
\hline 2015 & 2.30 & 2.24 & 0.06 & 0 & 0 & \\
\hline 2016 & 1.70 & 2.27 & -0.57 & 0.33 & 0.41 & \\
\hline 2017 & 2.50 & 2.21 & 0.29 & 0.08 & 0.74 & \\
\hline 2018 & 2.30 & 2.05 & 0.25 & 0.06 & 0 & \\
\hline 2019 & 1.70 & 1.79 & -0.09 & 0.01 & 0.12 & \\
\hline Total & & & & 19.05 & 52.27 & 3.006 \\
\hline
\end{tabular}

The calculation of the autocorrelation coefficient of deviations for lag 2, 3, 4 also confirmed the lack of significance, which eliminates the need for further analysis of this financial indicator. Thus, the changes in the real GDP growth for developed countries during 2008-2019 are random and reflect the lack of cyclicality. That is, changes in this indicator are due to fluctuations in the global financial cycle.

The next object of the analysis of the cyclical nature of the level of real GDP growth in 2008-2019 is a group of developing countries. According to the selected equation of the trend shown in Figure 3, the residuals and 
the Durbin - Watson statistic were calculated with the value 2.565 , which falls within the range of $1.023<2.565$ $<2.977\left(d_{2}<D W<4-d_{2}\right)$, i. e., there is no autocorrelation. Thus, for this group of countries, there is a random nature of fluctuations caused by both individual internal factors and external shifts in the global financial cycle, or certain countries, which are most influential.

Further, a methodological analysis of cyclical fluctuations in the level of real GDP growth for Ukraine was carried out. As a result, the Durbin - Watson statistic of 2.161 was obtained to verify the presence of autocorrelation for available data. This value confirmed the absence of autocorrelation $\left(1.023<2.161<2.977 ; d_{2}<D W<4-d_{2}\right)$, which indicates the acyclic behavior of the analyzed indicator to identify the nature of the periodicity of the local financial cycle of Ukraine during the period 2008-2019.

1 he next financial indicator to study cyclicality, which helps to identify cyclical fluctuations in local and global financial cycles, is the total amount of loans to the non-financial sector of the economy. The non-financial sector of the economy is a key element of economic growth and financial balance of any country, as it includes economic agents responsible for the economic development of the country and regular quality support of domestic and international economic relations. Therefore, it is necessary to take into account the performance of the non-financial sector of the economy in order to study the cyclical nature of local and global financial cycles. The changes in the total volume of loans granted to the nonfinancial sector for 2 groups of countries and Ukraine, as well as the selected trend equation, are shown in Fig. 3.

The first group of countries to analyze the periodicity of this indicator includes developed countries. As a result of calculating the Durbin - Watson statistic for the analyzed financial indicator, the obtained value of 1.003 $\left(0.697<1.003<1.023 ; d_{1}<D W<d_{2}\right)$ suggests the need to continue the study by going through the next step of the methodological approach to detect cyclicality.
Thecking the significance of the autocorrelation coefficient of first-order residuals for the total volume of loans to the nonfinancial sector based on Student's test showed statistical insignificance of the autocorrelation coefficient for lag $1\left(1.368<2.262 ; t_{p}<t_{a}\right)$. In this case, it is necessary to recalculate the autocorrelation coefficient of deviations of the residuals and check it for subsequent lags of the available time series. The repeated analysis of the autocorrelation coefficients of 2, 3 and 4 lags allowed us to conclude that the dynamics of the financial indicator for developed countries is random fluctuations and the hypothesis of absence of cyclicality.

For the group of developing countries, the Durbin Watson statistic with a value of $1.333(1.023<1.333$ $<2.977 ; d_{2}<D W<-d_{2}$ ) confirmed the hypothesis of no autocorrelation of residuals for the total amount of loans granted to nonfinancial sector of the economy. This indicates the absence of cyclicality in the local financial cycle of this group of countries during the period under analysis.

The situation is similar with the determination of the cyclical indicator of the total volume of loans granted to the non-financial sector of the economy in Ukraine. This is confirmed by the value of the Durbin - Watson statistic $-1.348\left(1.023<1.348<2.977 ; d_{2}<D W<4-d_{2}\right)$. The lack of autocorrelation of residuals in this case indicates the random nature of fluctuations in the analyzed indicator during 2008-2019, so some changes in the dynamics are associated with fluctuations in the global economic cycle.

Finally, the financial indicator that needs to be examined for cyclicality is characterized by the ratio of total loans to the non-financial sector of the economy to nominal GDP. This indicator characterizes the comparison of the total debt of the non-financial sector to the annual volume of nominal GDP, which to a greater extent includes the results of activity of all enterprises for 1 year. Thus, this indicator expresses the share of domestic debt of non-financial sector entities in their total an-

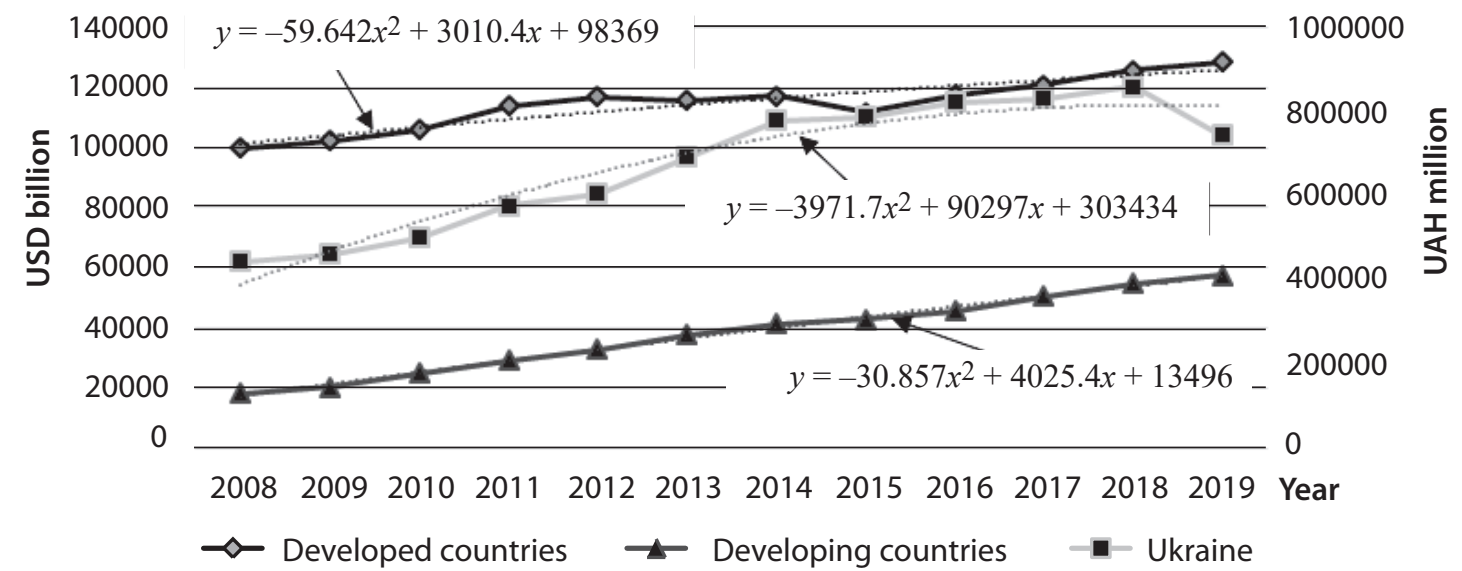

Fig. 3. Changes in total volume of loans to the non-financial sector of the economy in developed countries, developing countries and Ukraine (2008-2019)

Source: compiled by $[9 ; 10]$. 
nual income. The behavior of this financial indicator for 2 groups of countries and Ukraine with the trend equations given for further research is presented in Fig. 4.

The calculation of the Durbin - Watson statistic for the data series of each group of countries and Ukraine showed that there is no autocorrelation between the available residuals. For developed economies, the statistic is $2.224\left(1.023<2.224<2.977 ; d_{2}<D W<4-d_{2}\right)$, for developing countries $-1.195(1.023<1.195<2.977$; $\left.d_{2}<D W<4-d_{2}\right)$ and for Ukraine $-2.608(1.023<2.608$ $<2.977 ; d_{2}<D W<4-d_{2}$ ). This confirms the hypothesis of the random nature of the cyclicality of the analyzed financial indicator during 2008-2019 and also explains the lack of periodicity. This conclusion suggests the dependence of changes in local financial cycles on cyclical shifts in the global financial cycle.
$\mathrm{T}$ The final financial indicator for identifying the cyclical nature of the local financial cycle is the real estate price index. This factor is the root cause of the financial crisis of 2007-2009 and has a rather complex forecasting mechanism, as it can cause sudden crises, which will have a negative impact on activities of economic entities and the world economy as a whole. Therefore, the analysis of real estate prices among the selected categories of countries is a very important factor in identifying the cyclical nature of the economy of a country and the global economy. The behavior of the real estate price index for 2 groups of countries and Ukraine during the period 2008-2019 with the trend equations used during the assessment of cyclicality is shown in Fig. 5.

For the group of developed countries, the result of calculating the Durbin - Watson statistic with the value

Ratio, times

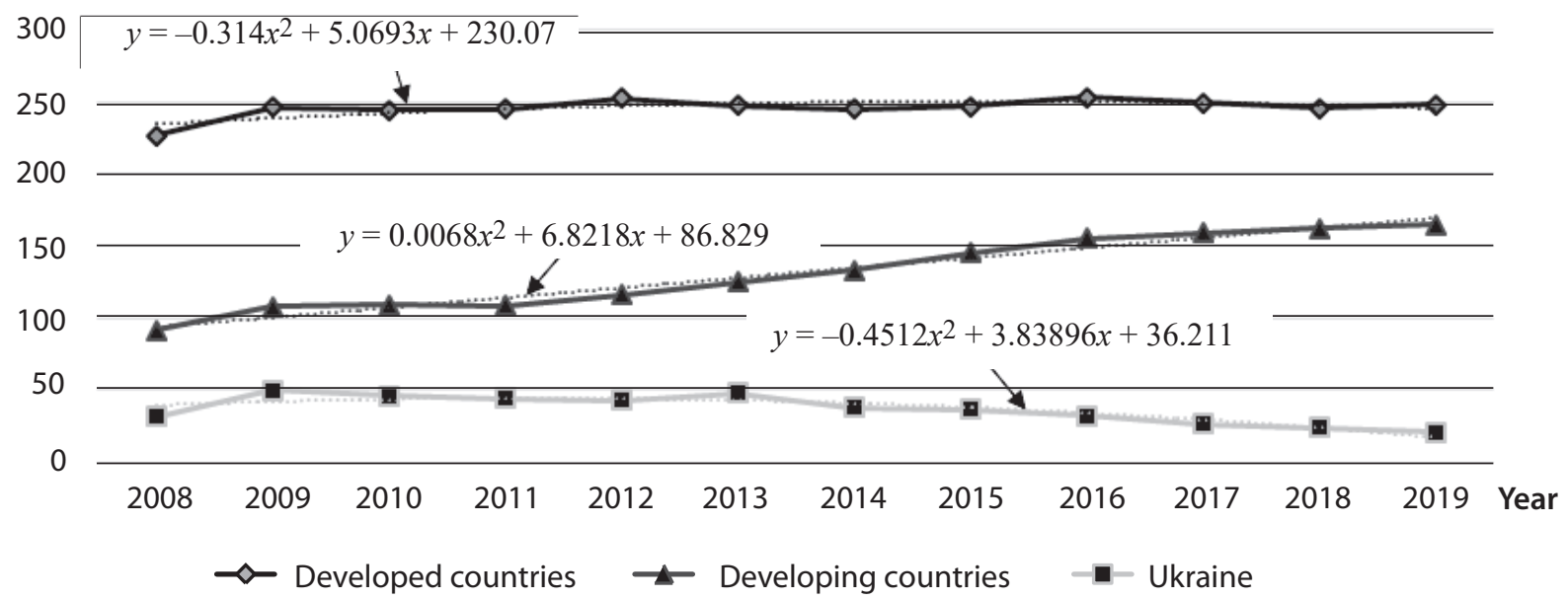

Fig. 4. The ratio of total loans to the non-financial sector of the economy to nominal GDP for developed countries, developing countries and Ukraine (2008-2019)

Source: compiled by [9-11].

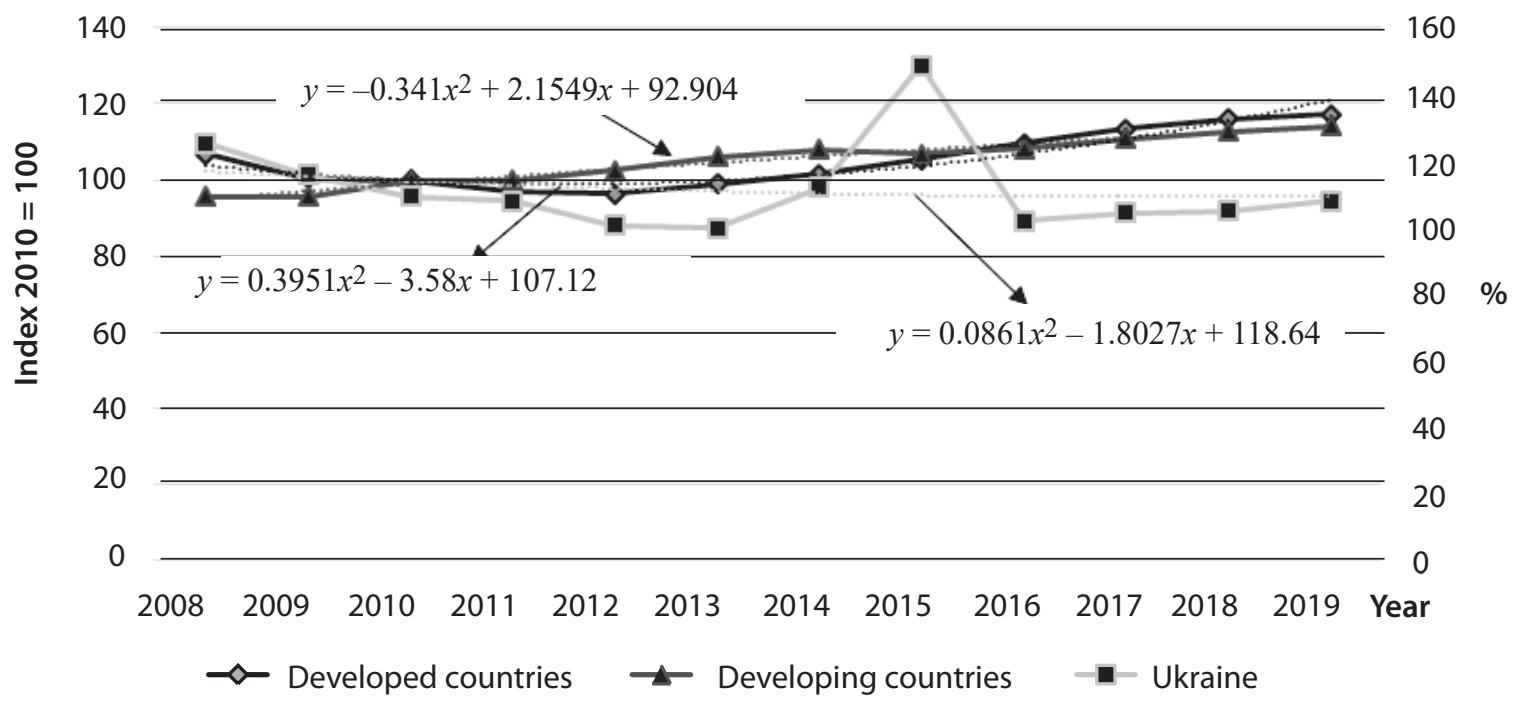

Fig. 5. Real estate price index in developed countries, developing countries and Ukraine (2008-2019) Source: compiled by [12; 13]. 
of $0.976\left(0.697<0.976<1.023 ; d_{1}<D W<d_{2}\right)$ indicates the need for a further more careful study of the autocorrelation of the residuals of the data series of the analyzed indicator.

$\mathrm{H}$ owever, the obtained autocorrelation coefficient of first-order residuals based on Student's test was insignificant. Subsequent recalculation of the autocorrelation coefficient for 2, 3, 4 lags showed the same result. Thus, we can confirm the hypothesis of the random nature of fluctuations in the real estate index for developed countries, which indicates the dependence of the local financial cycle on any changes in the global financial cycle.

For developing countries and Ukraine, the study of autocorrelation of residuals based on the Durbin - Watson statistic with values of 1.859 and 1.932, respectively, confirmed the hypothesis of no autocorrelation, i.e. non-periodicity of data. The non-cyclical nature of local financial cycles relative to the analyzed financial indicator confirmed the previous results of the analysis, based on which it can be concluded that local financial cycles tend to change under the influence of cyclical shifts in the global financial cycle, i.e., there is a direct relationship between fluctuations in local and global financial cycles.

\section{CONCLUSIONS}

As a result of the study of the cyclical nature of local financial cycles and their relationship with the global financial cycle, the following patterns were identified: 1) assessment of the periodicity of local financial cycles according to the relevant financial indicators indicates the absence of autocorrelation of the residuals of available data series, this contributes to the hypothesis of random fluctuations of cycles and their non-periodicity during 2008-2019; 2) changes that occur in the process of movement of the relevant financial indicators of local financial cycles depend on the cyclical shifts of the global financial cycle. Thus, it is possible to hypothesize the direct dependence of the occurrence of the respective phases in the local financial cycle on any recessions and booms during the cyclical fluctuations of the global financial cycle. However, the study was based on the analysis of aggregate indicators for 2 groups of countries. Thus, to confirm the cyclical nature of financial cycles, it is necessary to examine the changes in the analyzed indicators over the past $15-20$ years since there is a high probability of the next financial crisis in 2020, given the average duration of global financial cycle of 8-10 years.

\section{LITERATURE}

1. Drehmann M., Borio C., and Tsatsaronis K. Characterisf ing the Financial Cycle: Don't Lose Sight of the Medium Term! BIS Working Paper. 2012. No. 380 (June). URL: https://www.bis.org/publ/work380.pdf

2. Christiano L., and T. Fitzgerald. The Band Pass Filter. International Economic Review. 2003. Vol. 44. Issue 2. P. 435-465.

DOI: https://doi.org/10.1111/1468-2354.t01-1-00076
3. Rey H. Dilemma not Trilemma: The Global Financial Cycle and Monetary Policy Independence. NBER Working Paper. 2015. No. 21162. P. 285-333.

DOI: https://doi.org/10.3386/w21162

4. Gorton G., and Ordonez G. Good Booms, Bad Booms. NBER Working Paper. 2016. No. 22008.

DOI: https://dx.doi.org/10.2139/ssrn.2398401

5. Giordani P., Spector E., Zhang X. A New Early Warning Indicator of Financial Fragility in Sweden. Sveriges Riksbank. Economic Commentaries. 19 January 2017. No. 1. URL: https://www.riksbank.se/globalassets/media/rapporter/ekonomiska-kommentarer/ engelska/2017/a-new-early-warning-indicator-offinancial-fragility-in-sweden.pdf

6. Jordà Ò., Schularick M., Taylor A. and Ward F. Global financial cycles and risk premiums. NBER Working Papers. 2018. No 24677, June.

DOI: https://doi.org/10.24148/wp2018-05

7. Real GDP growth / IMF. URL: https://www.imf.org/external/datamapper/NGDP_RPCH@WEO/OEMDC/ADVEC/WEOWORLD

8. Watson P. K., Teelucksingh S. S. A Practical Introduction to Econometric Methods: Classical and Modern. University of the West Indies Press, Jamaica. 2002. 320 p.

9. Total Credit to Private Non-Financial Sector / Bank for International Settlements. URL: https://fred.stlouisfed. org/series/Q5RPAM799A

10. Monetary statistics / National Bank of Ukraine. URL: https://bank.gov.ua/statistic/sector-financial/datasector-financial

11. GDP, current prices / IMF. URL: https://www.imf.org/ external/datamapper/NGDPD@WEO/WEOWORLD

12. Real Residential Property Prices / Bank for International Settlements. URL: https://fred.stlouisfed.org/series/ Q4TR628BIS

13. Statistical Information / State Statistics Service of Ukraine. URL: https://ukrstat.org/en/operativ/oper_ new_e.html

\section{REFERENCES}

Christiano, L., and Fitzgerald, T. "The Band Pass Filter". International Economic Review, vol. 44, no. 2 (2003): 435-465. DOI: https://doi.org/10.1111/1468-2354.t01-1-00076

Drehmann, M., Borio, C., and Tsatsaronis, K. "Characterising the Financial Cycle: Don't Lose Sight of the Medium Term!". BIS Working Paper. 2012. https://www.bis.org/ publ/work380.pdf

"GDP, current prices". IMF. https://www.imf.org/external/ datamapper/NGDPD@WEO/WEOWORLD

Giordani, P., Spector, E., and Zhang, X. "A New Early Warning Indicator of Financial Fragility in Sweden". Sveriges Riksbank. Economic Commentaries. 19 January 2017. https://www.riksbank.se/globalassets/media/rapporter/ekonomiska-kommentarer/engelska/2017/anew-early-warning-indicator-of-financial-fragility-insweden.pdf

Gorton, G., and Ordonez, G. "Good Booms, Bad Booms". NBER Working Paper, no. 22008 (2016). DOI: https://dx.doi.org/10.2139/ssrn.2398401

Jorda, O. et al. "Global financial cycles and risk premiums". NBER Working Papers, June, no. 24677 (2018). DOI: https://doi.org/10.24148/wp2018-05 
"Monetary statistics". National Bank of Ukraine. https:// bank.gov.ua/statistic/sector-financial/data-sectorfinancial

"Real GDP growth". IMF. https://www.imf.org/external/ datamapper/NGDP_RPCH@WEO/OEMDC/ADVEC/ WEOWORLD

"Real Residential Property Prices". Bank for International Settlements. https://fred.stlouisfed.org/series/Q4TR628BIS

Rey, H. "Dilemma not Trilemma: The Global Financial Cycle and Monetary Policy Independence". NBER Working
Paper, no. 21162 (2015): 285-333.

DOI: https://doi.org/10.3386/w21162

"Statistical Information". State Statistics Service of Ukraine. https://ukrstat.org/en/operativ/oper_new_e.html

"Total Credit to Private Non-Financial Sector". Bank for International Settlements. https://fred.stlouisfed.org/ series/Q5RPAM799A

Watson, P. K., and Teelucksingh, S. S. A Practical Introduction to Econometric Methods: Classical and Modern. Jamaica: University of the West Indies Press, 2002.

\section{ФУНКЦІОНУВАННЯ РИНКУ ВНУТРІШНІХ ДЕРЖАВНИХ ЗАПОЗИЧЕНЬ В УКРАЇНІ ${ }^{\odot 2020 ~ Б Е Н Ч ~ Л . ~ Я ., ~ К О Л Я Д А ~ Т . ~ А ., ~ Б А И ̆ ~ А . ~} 0$.}

УДК 336.273 .2

JEL: G18; G28; H27; H62; H63; H81

\section{Бенч Л. Я., Коляда Т. А., Бай А. О. Функціонування ринку внутрішніх державних запозичень в Україні}

Метою статті є розкриття особливостей функціонування ринку внутрішніх державних позик в Україні; визначення основних тенденцій його розвитку та розробка пропозицій щодо вдосконалення системи внутрішніх державних запозичень. Розкрито сутність та особливості здійснення внутрішніх державних запозичень в Україні; наведено оцінку функціонування системи внутрішніх державних запозичень; виявлено основні тенденцій розвитку ринку внутрішніх державних позик на основі аналізу динамки платежів за внутрішнім державним боргом, обсягів розмішення облігацій внутрішніх державних позик (ОВДП) на первинному ринку та граничного рівня дохідності облігацій протягом 2013-2019 рр. Досліджено ефективність функціонування ринку внутрішніх державних позик в Україні за допомогою аналізу строковості ОВДП, обсягів розміщення короткострокових ОВДП, номінальної та реальної дохідності короткострокових ОВДП за період 2013-2019рр. 3'ясовано основні проблеми функціонування ринку внутрішніх державних запозичень в Україні. Обгрунтовано пропозиції щодо покращення подальшого фрункціонування ринку внутрішніх державних запозичень. Перспективою подальших досліджень у даному напрямі $\epsilon$ доведення необхідності при розробці фінансової політики держави акцентувати увагу на диференціації інструментів фінансового ринку та посиленні їх використання як джерела інвестиційних ресурсів держави. Ключові слова: внутрішні державні запозичення, внутрішній державний борг, облігації внутрішніх державних позик, джерела фінансування дефіциту бюджету, фінансові інструменти фондового ринку.

DOI: https://doi.org/10.32983/2222-4459-2020-6-259-266

Рuс.: 8. Табл.: 1. Бібл.: 11.

Бенч Лілія Ярославівна - кандидат економічних наук, доцент, доцент кафедри фінансів, Київський національний економічний університет ім. В. Гетьмана (просп. Перемоги, 54/1, Київ, 03057, Україна)

E-mail: benchliliya@gmail.com

ORCID: https://orcid.org/0000-0002-4215-7925

Коляда Тетяна Анатоліївна - кандидат економічних наук, старший науковий співробітник, доцент кафедри фінансів імені Л. Л. Тарангул, Університет державної фіскальної служби України (вул. Університетська, 31, Ірпінь, 08201, Україна)

E-mail: t.a.koliada@gmail.com

ORCID: $h$ ttps://orcid.org/0000-0002-1574-4446

Researcher ID: http://www.researcherid.com/U-2474-2018

SPIN: http://elibrary.ru/9246-0311

Бай Анна Олексіївна - студентка факультету фінансів, Київський національний економічний університет ім. В. Гетьмана (просп. Перемоги, 54/1, Київ, 03057, україна)

E-mail: anyabay1999@gmail.com

УДК 336.273 .2

JEL: G18; G28; H27; H62; H63; H81

Бенч Л. Я., Коляда Т. А., Бай А. А. Функционирование рынка внутренних государственных заимствований в Украине

Целью статьи является раскрытие особенностей функционирования рынка внутренних государственных займов в Украине; определение основных тенденций его развития и разработка предложений относительно совершенствования системы внутренних государственных заимствований. Раскрыта сущность и особенности осуществления внутренних государственных заимствований в Украине; приведена оценка функционирования системы внутренних государственных заимствований; выявлены основные тенденции развития рынка внутренних государственных займов на основе анализа: динамки платежей по внутреннему государственному долгу, объемов размещения облигаций внутренних государственных займов (ОВГЗ) на первичном рынке и предельного уровня доходности облигаций в течение 2013-2019 гг. Исследована эффективность функционирования рынка внутренних государственных займов в Украине с помощью анализа сроков заимствования ОвГз, объемов размещения краткосрочных ОВГЗ, номинальной и реальной доходности краткосрочных ОВГЗ за период 2013-2019 г2. Выяснены основные проблемы функционирования рынка внутренних государственных заимствований в Украине. Обоснованы предложения относительно улучшения дальнейшего функционирования рынка внутренних государственных заимствований. Перспективой дальнейших исследований в данном направлении является доведение необходимости при разработке финансовой политики государства акцентировать внимание на дифференциации инструментов финансового рынка и усилении их использования как источника инвестиционных ресурсов государства. 